7. Reprod. Fert. (1968) 17, 177-178

\title{
LEVELS OF CERTAIN SOLUBLE DEHYDROGENASES IN THE RAT TESTIS AND EPIDIDYMIS
}

\author{
T. LUNAAS, * R. L. BALDWIN AND P. T. GUPPS \\ Department of Animal Husbandry, University of California, Davis, California
}

(Received 25th March 1968)

Reduced nicotinamide-adenine dinucleotide phosphate (NADPH), required as co-factor for lipogenesis and steroidogenesis, may, in part, be supplied by pyridine nucleotide transhydrogenation mediated by malate dehydrogenase (oxaloacetate $+\mathrm{NADH} \rightarrow$ malate $+\mathrm{NAD}$ ) and the malate ('malic') enzyme (malate $+\mathrm{NADP} \rightarrow$ pyruvate $\left.+\mathrm{CO}_{2}+\mathrm{NADPH}\right)$. The malate transhydrogenation reactions (cf. Ballard \& Hanson, 1967, for references) are apparently of some importance in luteinized rat ovaries in which glucose-6-phosphate dehydrogenase is by far exceeded in activity by the malate enzyme (Lunaas \&

TABLE 1

DEHYDROGENASES IN TESTIS AND CAPUT EPIDIDYMIDIS

IN THE RAT (SPRAGUE-DAWLEY, $n=5$ )

\begin{tabular}{l|r|r}
\hline & Substrate and co-factor & \multicolumn{1}{|c}{$\begin{array}{c}\text { Caput } \\
\text { epididymidis }\end{array}$} \\
\hline A. Malate; NADP & $2 \cdot 16 \pm 0.16$ & $0.92 \pm 0.07$ \\
B. Glucose-6-P; NADP & $0.53 \pm 0.06$ & $3.18 \pm 0.27$ \\
C. 6-P-Gluconate; NADP & $0.94 \pm 0.04$ & $1.98 \pm 0.13$ \\
D. Isocitrate; NADP & $1.55 \pm 0.05$ & $1.91 \pm 0.22$ \\
E. Malate; NAD & $5.53 \pm 0.68$ & $13.52 \pm 0.75$ \\
Ratio, A: & $4.18 \pm 0.51$ & $0.29 \pm 0.03$ \\
Ratio, C: & $1.85 \pm 0.20$ & $0.61 \pm 0.09$ \\
\hline
\end{tabular}

* Means \pm SD of activities expressed as $\mu$ moles of product formed $\mathrm{min} / \mathrm{g}$ tissue. Spectrophotometric assays at room temperature of $30,000 \mathrm{~g}$ supernatants (Baldwin \& Milligan, 1965).

Baldwin, 1967). In rat testes high activities of the malate enzyme and of isocitrate dehydrogenase were reported by Brown, McLean \& Greenbaum (1966). We have confirmed these findings (Table 1). In addition we determined glucose-6-phosphate dehydrogenase, 6-phospho-gluconate dehydrogenase and the $\operatorname{NAD}(\mathrm{H})$-dependent malate dehydrogenase. Remarkably low levels were consistently obtained for glucose-6-phosphate dehydrogenase, the apparent activity of this enzyme in the testes being even lower than that of the 6-phosphogluconate dehydrogenase.

In epididymal tissue the malate enzyme activity amounted to less than onehalf of testicular activity but the level of glucose-6-phosphate dehydrogenase

* Present address: Department of Reproductive Physiology and Pathology, Veterinary College of Norway, Oslo, Norway. 
was about six times as high as in the testes. These results seem to indicate that the two tissues differ with respect to the relative importance of the hexose monophosphate shunt and the malate transhydrogenation reactions as a source of NADPH.

Citrate cleavage, leading to the formation of oxaloacetate and acetate-CoA, presumably takes place in the testes of the rat (Brown et al., 1966). By supporting oxaloacetate removal, the malate transhydrogenation reactions may be involved in generation of activated acetate fragments and, thereby, in lipogenesis by the testis. It is known that the testes have several types of cells containing lipids, namely, the spermatogenic and Sertoli cells in the tubuli, and Leydig cells in the interstitium. The interstitial cells are also known to contain malate dehydrogenase (Ambadkar \& George, 1964) as well as glucose-6-phosphate dehydrogenase (Niemi \& Ikonen, 1962). As judged from histochemical studies in bull organs (Blackshaw \& Samisoni, 1967), the high activity of glucose-6phosphate dehydrogenase found in the epididymis is probably localized in the tubule cells, which are holocrine in function.

This investigation was supported in part by a Public Health Service International Postdoctoral Research Fellowship (No. F 05 TW 940-01) and in part by USPHS grant No. AMO 7672 .

\section{REFERENCES}

Ambadkar, P. M. \& George, J. C. (1964) Histochemical localization of certain oxidative enzymes in the rat testis. F. Histochem. Cytochem. 12, 587.

Baldwin, R. L. \& Milligan, L. P. (1965) Enzymatic changes associated with the initiation and maintenance of lactation in the rat. F. biol. Chem. 241, 2058.

Ballard, F. J. \& Hanson, R. W. (1967) The citrate cleavage pathway and lipogenesis in rat adipose tissue: replenishment of oxaloacetate. 7. Lipid Res. 8, 73.

Blackshaw, A. W. \& SAmisoni, J. I. (1967) Histochemical localization of some dehydrogenase enzymes in the bull testis and epididymis. F. Dairy Sci. 50, 747.

Brown, J., McLean, P. \& Greenbaum, A. L. (1966) Influence of thyroxine and luteinizing hormone on some enzymes concerned with lipogenesis in adipose tissue, testis and adrenal gland. Biochem. 7. $101,197$.

LunAAS, T. \& BALDWIN, R. L. (1967) Effect of oestradiol-17 $\beta$ and of 1-thyroxine on activities of ovarian pyridine nucleotide dependent dehydrogenases in the lactating rat. $\mathcal{7}$. Endocr. 39, 121.

NiEmi, M. \& IKonEN, M. (1962) Cytochemistry of oxidative enzyme systems in the Leydig cells of the rat testis and their functional significance. Endocrinology, 70, 167. 